\title{
ПЕТРОФАЦИАЛЬНЫЙ АНАЛИЗ И ПЕТРОФИЗИЧЕСКИЕ МОДЕЛИ ПЛАСТА Ю1 КРЕЩЕНСКОГО МЕСТОРОЖДЕНИЯ
}

Исаев Г.Д., Дорогиниикая Л.М., Голиков Н.А.

(ООО Научно- исследовательский иентр "Сибгеонафт», ООО "Сибоетролаб̈»)

Аннотация.

Фациальные условия осадконакопления определяют текстуру, гранулометрический и минеральный состав пород, а вследствие этого и структуру их порового пространства и петрофизические уравнения, используемые при количественной интерпретации материалов ГИС. Построение связей по фациальному признаку позволяет уточнять модели, включающие как основной прогнозирующий признак- пористость пород.

Пласт Ю1 на Крещенской площади представлен песцаными породами глубоководного конуса выноса (ГКВ). ГКВ сформирован серией плотностных гравитационных потоков из материала края шельфа. Обычно такой ГКВ в основания имеет нижнюю "мусорную пачку», которая в рассматриваемом разрезе отсутствует. Средняя или иентральная часть $Г К B$ с признаками лавинной седиментации вскрыта на глубине 3147,2-3157,6м. Верхняя часть ГКВ вскрыта в интервале $3142,1-3147,2$ м и характеризуется крайней текстурной неоднородностью. Верхняя часть ГКВ фачиально и по физкческим свойствам четко делится на две пачки. Верхняя представляет собой деструктивный «мусорный» комплекс осадков перехода к перекрывающей глинистой толще и имеет средние значения пористости $13,1 \%$ и проницаемости Кпр $=0,62$ мД. Нижняя клиноформенная существенно песчаная с высокими коллекторскими свойствами, $\mathrm{Kn}=17,2 \%$, Кпр=234мД. Лавинная или чентральная часть ГКВ представлена массивными мелкозернистыми и песчаниками $\mathrm{c}$ переменчивой градационной слоистостью. Коллекторские свойства лавинной части ГКВ, начиная со срединной ее части, осложнила вторичная карбонитизация. Верхняя пачка имеет лучшие в разрезе коллекторские свойства, Кп=19,8\% и Кпр=376 мД. За счет появления вторичного карбонатного цемента средняя пачка и нижняя имеют пористость $18,3 \%$ и $17,6 \%$, а проницаемость 88,8 мД и 32,8 мд соответственно.

С помощью корреляционного анализа показано, что кроме текстурных особенностей породы разной фациальной принадлежности различаются гранулометрическими характеристиками и составом цемента. Указанные литологические факторы определяют различия в распределение пор и поровых каналов по размерам. Физические свойства пород зависят от строения пустотного пространство по разному. Теоретически пористость зернистых структур не зависит от размеров межзерновых пор, а проницаемость, остаточная водонасыщенность и удельная электропроводность определяются главным образом структурой и размерами пустот. Таким образом, у пород разных фациальных зон следует ожкидать, например, разные связи Кпр(Кп), Кво(Кп) и $\operatorname{Pr}(\mathrm{K})$. Это хорошо демонстрирует рис.1. Между тем можно наблюдать единые связи для свойств и параметров, в равной степени определяющихся структурой порового пространства, рис. 2 .

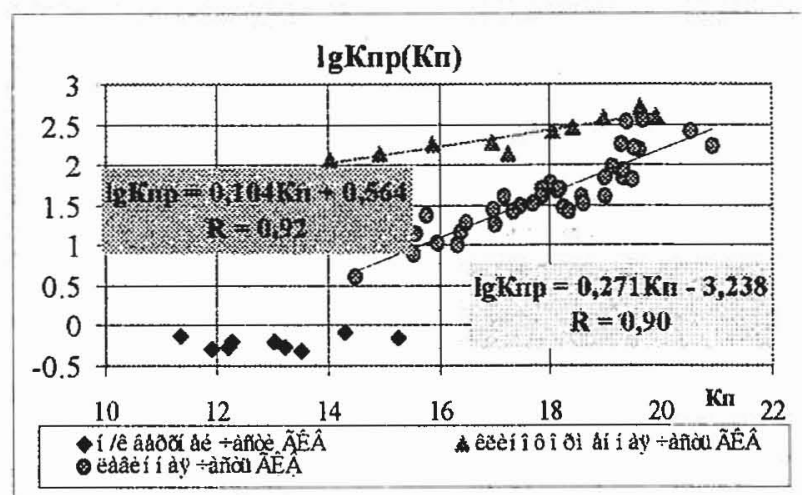

Рис. 1. Зависимости между прожицаемостью, остаточной водонасыщенностью и пористостью.

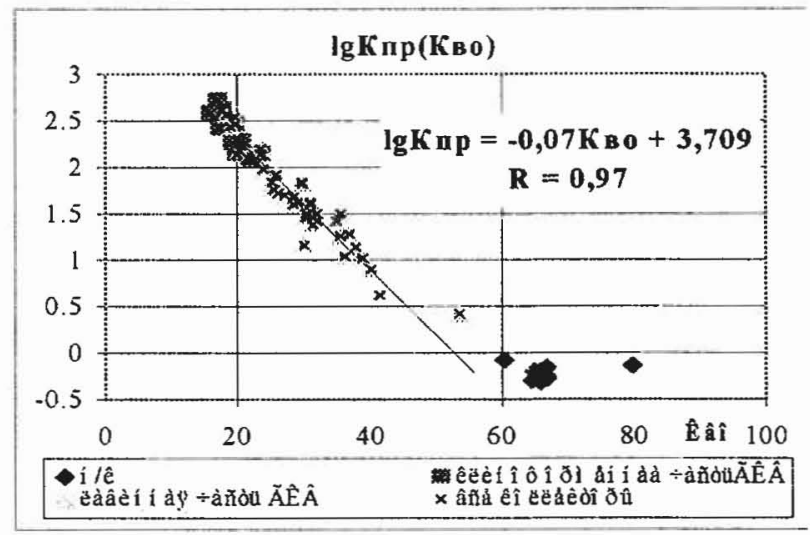

Рис.2. Зависимости между свойствами равноветико опредетяемых структурой порового пространства.

Подмеченные закономерности имеют большое прикладное значение, поскольку рассмотренные выте петрофизические модели используются для количественной интерпретации материалов ГИС. Следует отметить, что при этом модели с использованием пористости являются по сути единственными при оценке проницаемости коллекторов. Особое значение имеет уточнение зависимости $\mathrm{Pп}(\mathrm{K})$, по которой определяется сопротивление водонасьщенной породы, а далее и ее нефте-газонасыщенность. 